\title{
POSSIBLE CHOICES OF MATERIALS AND METHODS FOR RESTORATION OF PERMANENT TEETH IN PEDIATRIC DENTISTRY
}

\author{
Milena Georgieva ${ }^{1}$, Evgeni Dimitrov ${ }^{1}$, Radosveta Andreeva ${ }^{1}$, Teodora Nikolova ${ }^{1}$, \\ Hristina Arnautska ${ }^{2}$, Elitsa Sabeva ${ }^{3}$ \\ ${ }^{1}$ Department of Pediatric Dentistry, Faculty of Dental Medicine, \\ Medical University of Varna \\ ${ }^{2}$ Department of Orthodontics, Faculty of Dental Medicine, Medical University of Varna \\ ${ }^{3}$ Department of Periodontology and Dental Implantology, Faculty of Dental Medicine, \\ Medical University of Varna
}

\begin{abstract}
Adolescents are defined as patients with significant dental needs as a result of: acute and fast progression of the carious process, high risk of traumas and periodontal diseases, bad nutrition habits, requirements for aesthetics and information, a complex of orthodontic and restorative treatment (for example, hypodontia), dental phobia, a possible use of tobacco, alcohol and drugs, pregnancy, nutrition disorders, and unique psychological needs. Adolescence is a period of life connected with high carious activity among many patients. The immature enamel of the permanent teeth, along with the increasing number of contact surfaces, the relative autonomy in the decisions about dental treatment, poor oral hygiene, may have a positive effect on the development of the carious process in adolescents. The most common restorative materials, used in the teenage years are resin composites and other resin-modified materials, glass-ionomer cements, silver amalgam and stainless steel alloys. Yet ceramics and casting alloys are rarely used in pediatric dentistry. In the cases where the remineralization of non-caved demineralized surfaces of tooth fails and the carious process continues dental restorations are needed. The choice of the restoration material and treatment method are based on the every patient's individual needs, requirements for aesthetics and the necessity to protect dental structures.
\end{abstract}

Keywords: amalgam, composite, glass-ionomer cements, inlays, ceramics

Address for correspondence: Milena Georgieva-Dimitrova Faculty of Dental Medicine 84. Tsar Osvoboditel Blvd. 9000 Varna e-mail:dr.milena.georgieva89@gmail.com

Received: December 3, 2017

Accepted: December 29, 2017
Dental amalgam is the most common restoration material used on distal teeth for more than 150 years and it is still used today worldwide (1). In the last decade its use has decreased $(1,2)$, perhaps due to the contradictory opinions about the negative effect of mercury vapors on general health, concerns for the nature, and the high requirements for aesthetics. In terms of amalgam safety, there is no evidence in dental medicine researches between 2004 and 2008 
Milena Georgieva, Evgeni Dimitrov, Radosveta Andreeva et al.

of mercury leakage from the amalgam and medical complaints of any nature (3). The efficiency of the amalgam in class I permanent teeth restorations is reported by two autonomous surveys and it varied from $89.8 \%$ to $98.8 \%$ for a period of seven years (1). The amalgam is not considered as the best restorative material for carious lesions on the occlusal surfaces of permanent molars anymore. The necessity of retention and certain depth may cause undermining of the occlusal marginal ridges and weakens the mechanical durability of the cusps, which may fracture. Thus these teeth may need even bigger restorations with risk of pulp exposure, root canal treatment and crown placement $(3,4)$.

Resin composites were implemented in the field of dental medicine half a century ago as an aesthetic alternative to restoration materials $(5,6)$. In more recent times they have been used more often for restoration of carious defects instead of amalgam (7). The durability of the composites depends on several factors including the clinician's experience, size of the restoration, and tooth's position (8). In the cases where the isolation and the patient's cooperation are problematic, composites may not be the proper choice of filling material (4). Nowadays, resin composites are used for restorations of class I, II, III, IV and $\mathrm{V}$ carious lesions in permanent and primary dentition (2). In historical aspect the problem of the marginal micro-leakage between the tooth's surface and the filling material has been described. In such cases composites are used to restore teeth in the distal area. The failure of the adhesion of the composite to dental structures and the bubbles in the material itself are considered a reason of inadequate marginal adaptation (2). Other main problems in the restoration of distal teeth is the polymerization compression of the material. Most of the composite resins show a linear compression of around $2 \%$ during the polymerization process. As a result high micro-leakage may occur (9). This problem may be solved in cases of distal teeth restoration by using contemporary composite materials, which contain high volume of fillers, reducing the polymerization compression; by chamfering the enamel edges, by using dentin-adhesive agents and etching of the enamel (2). High mechanical durability and abrasion resistance make resin composites better choice of filling material in comparison to glass-ionomer cements when treating small occlusal carious lesions on permanent teeth (3).

Glass-ionomer cements (GIC) were used in dentistry as a filling material, bases and luting agents in the 1970s $(2,9)$. All glass-ionomer cements have several properties which make them a good choice material to be used in children's dental treatment: chemical bond to the enamel and dentin, thermal expansion similar to the one in dental structures; biocompatibility; accumulation and fluoride-releasing potential; good moisture tolerance compared to composite materials $(10,11)$. For class II restorations a randomized control trial shows unacceptably high rates of failure of the conventional GIC, regardless of the size of the cavity. There is insufficient evidence for resin-modified GIC application as a long-term restoration in permanent teeth (1).

Compomers were used for the first time in dental practice at the end of the last century. They contain $72 \%$ strontium-fluoro-silicate glass filler. Compomers have the properties of composites as well as those of glass-ionomer cements. It is expected for the compomer to have the durability, abrasion resistance, color resistance and polishability of the composites. The compomers polymerize under the effect of ultraviolet light (3). Acid-alkaline reaction occurs in the compomer, but it is not the main reaction of polymerization. Thus, light-curing is necessary to perform the polymerization reaction (2). The successful adhesion of the material to the hard tooth tissues requires the use of enamel and dentin bonding systems (3). Considering the fluorine-releasing potential, the aesthetic quality and working conditions of compomers make them preferred restoration material in pediatric dentistry. There is not enough evidence, comparing compomers with other restorative materials in permanent children's teeth (1-3).

Instead of pure metals, dental alloys play a significant part in the treatment of dental caries, because pure metals do not have the needed physical properties for dental restorations in the oral cavity (12). In the operative treatment cast metal restorations are used mainly in three different forms: inlays, overlays and partial dental crowns. They are made in at least two stages. In the first visitation, the tooth is prepared and this is followed by an impression. In the second visitation, the cast metal restora- 
tion is cemented over the tooth $(12,13)$. Cast metal inlays are used on teeth where: an extensive caries is observed on the proximal surfaces of the distal teeth, after an endodontic treatment of molars and premolars strengthening the rest of the hard tooth tissues, in cases of fractures of enamel and dentin where an extensive restoration of the proximal contacts and contours is needed, as well as necessary corrections in the occlusal plane, for restorations of teeth intended to carry removable prosthesis, in distal teeth, undergoing strong masticatory pressure and abrasion (2,13-15).

The aesthetic restorations performed in the oral cavity are called indirect aesthetic inlays. The indirect restorations are performed on models presenting the exact same situation in the oral cavity after previous preparation of the tooth. This method includes laboratory modeling of ceramics or resin composites $(13,15-17)$. They are used on teeth with large defects, mainly in class I and II, with wide bucco-lingual size and when a cusp covering is necessary. The contours of the large indirect restorations are performed more easily and they are more durable compared to direct composite fillings especially in the areas of occlusal contacts. The ability to resist the strong masticatory pressure is extremely important in extensive restorations in the distal areas (13). The restoration with indirect aesthetic inlays is a contraindication in cases with bruxism and bruxomania, where there is inadequate moisture control at deep subgingival defects (hard up impression, as well as finishing manipulations concerning the cementing of this kind restoration) $(13,18)$. There are many advantages of the aesthetic direct restorations - less clinical time, more accurate restoration of the contact points and the contours of the tooth surface, they are more resistant to abrasion compared to the direct composite fillings, the compatibility is better, also they strengthen the rest of the hard tooth tissues through the use of adhesive systems in the cementing process, they have improved physical properties, there is diversity of materials and better output techniques $(13,15,16,19,20)$. The disadvantages of indirect aesthetic restorations are: high cost, the necessity of temporary filling, more visitations, they are technique sensitive and require high level of experience of the dentist, adhesion of the indirect composite fillings, where composite cement is used as a cementing agent, weakness, which requires a previous mechanical abrasion and/or chemical treatment of the inlay. Ceramic material is a fragile one and if the preparation does not allow enough thickness of the inlay a possible fracture may occur during or after cementation $(13,19)$. Composite materials with improved strength and abrasion resistance are now available on the market and are becoming more and more popular. Alongside with the improvement of the resin-modified cements and the dentin adhesive systems, indirect composite restorations (reinforced or not with Kevlar fibers) may be considered a proper restorative agent in cases of single inlay, overlay or a crown. Composite resin materials are usually preferred over ceramics for inlays, while ceramics are better for overlays and crowns (11). The additional clinical advantages include not only a precise marginal adaptation and abrasive resistance, similar to the one in the enamel, compatibility with the antagonist natural dentition, but also an ideal recreation of interdental contact points, excellent morphological features and optimal aesthetics (20-22). Indirect composite inlays/overlays are more resistant to functional abrasion than direct ones, but less than ceramics $(5,13,20)$. Combined inlays are indicated when the gingival border of the prepared cavity is located at the level of margo gingivalis. The preparation is the same as it is in the cases of cast metal inlays. All ceramic restorations have perfect aesthetic properties but they are fragile and may suffer future fractures. All metal restorations are durable but with poor aesthetics. The aesthetics of the ceramics and the strength of the metal are combined in metal-ceramic restorations $(15,17,18,23-25)$. The bond between metal and ceramics must be strong and durable, because the most common reason of failure of the restoration is where the ceramics is peeled off the metal $(26,27)$. The compatibility between the alloy and the ceramics is extremely important. The metal must not interact with the ceramics, because this may disturb the aesthetics $(28,29)$.

The ceramic inlay and overlay become more and more popular as alternative restorations in the distal areas instead of direct composite fillings. They have better abrasion resistance compared to composite resins, therefore they last longer. However, the occlusal corrections are more difficult and may lead to faster functional abrasion of the natural antagonist if 
Milena Georgieva, Evgeni Dimitrov, Radosveta Andreeva et al.

the restorations are not properly polished or adjusted $(12,24,28,29)$. The functional and aesthetic restorations for severely damaged teeth require materials, which must be biocompatible, mechanically stable during mastication and compatible with the natural tooth color. In summary ceramic inlays and partial crowns are clinically acceptable alternatives of the metal inlays and amalgam restorations when restoring one or more cusps $(18,25,27,30-33)$.

\section{REFERENCES}

1. American Academy of Pediatric Dentistry. Guideline on restorative dentistry. Pediatr Dent. 2015;37(special issue): 232-43.

2. Council ADA. Biocompatibility of dental alloys. J Am Dent Assoc. 2002;133:758e9.

3. Pinkham J, Casamassimo P, Fields H, McTigue D, Nowak A. Pediatric Dentistry: Infancy through Adolescence. Mosby;2005. p. 331-40.

4. Antony K, Genser D, Hiebinger C, Windisch F. Longevity of dental amalgam in comparison to composite materials. GMS Health Technol Assess. 2008;13(4):Doc12.

5. Leinfelder KF. Posterior composite resins. J Am Dent Assoc. 1988;117(4):21E-26E.

6. Minguez N, Ellacuria J, Soler JI, Triana R, Ibaseta G. Advances in the history of composite resins. J Hist Dent. 2003;51(3):103-5.

7. Opdam NJ, Bronkhorst EM, Loomans BA, Huysmans MC. 12-year survival of composite vs. Amalgam restorations. J Dent Res. 2010;89(10):1063-7. doi: $10.1177 / 0022034510376071$.

8. Cameron A, Widmer R. Handbook of Pediatric Dentistry. Germany: Mosby;2013.p. 93-102.

9. Avery DR, Dean JA, McDonald RE. McDonald and Avery's Dentistry for the Child and Adolescent. Mosby;2008.p.322-42.

10. Vallittu P. Non-Metallic Biomaterials for Tooth Repair and Replacement. Woodhead Publishing; 2012.p. 133-55.

11. Walmsley DA, Walsh T, Lumley P, Burke TJ, Shortall CA, Hayes-Hall R, et al. Restorative Dentistry. Churchill Livingstone;2007. p. 124-34.

12. Wataha JC, Messer RL. Casting alloys. Dent Clin North Am. 2004;48(2):499-512. doi: 10.1016/j. cden.2003.12.010.
13. Garg A, Garg N. Textbook of Operative Dentistry. Jaypee Brothers Medical Publishers; 2007. p. 284- 303.

14. Dahl BL, Carlsson GE, Ekfeldt A. Occlusal wear of teeth and restorative materials. A review of classification, etiology, mechanisms of wear, and some aspects of restorative procedures. Acta Odontol Scand. 1993;51(5): 299-311.

15. Ekfeldt A, Oilo G. Wear of prosthodontic materials - an in vivo study. J Oral Rehabil. 1990;17(2):117-29.

16. Anusavice KJ. Phillips' science of dental materials. 11th ed. St Louis: Elsevier; 2003. p. 431-8, 539, 702.

17. Dahl B, Øilo G. Wear of teeth and restorative materials. In: Owall B, Kayser AF, Carlsson GE, editors. Prosthodontics. Principles and management strategies. London: Mosby-Wolfe; 1996. p. 187-200.

18. Hickel R, Manhart J. Longevity of restorations in posterior teeth and reasons for failure. J Adhes Dent. 2001;3(1):45-64.

19. Stappert CF, Guess PC, Gerds T, Strub JR. All-ceramic partial coverage premolar restorations. Cavity preparation design, reliability and fracture resistance after fatigue. Am J Dent. 2005;18(4):275-80.

20. Touati B, Aidan N. Second generation laboratory composite resins for indirect restorations. J Esthet Dent. 1997; 9(3):108-18.

21. Howard NY. Advanced use of an esthetic indirect posterior resin system. Compend Contin Educ Dent. 1997;18(10):1044-54.

22. Leinfelder KF. Indirect posterior composite resins. Compend Contin Educ Dent. 2005;26(7):495-503.

23. Bernardo M, Luis H, Martin MD, Leroux BG, Rue T, Leitão J, et al. Survival and reasons for failure of amalgam versus composite posterior restorations placed in a randomized clinical trial. J Am Dent Assoc. 2007;138(6):775-83.

24. Powers JM, Sakaguchi RL. Craig's Restorative Dental Materials. Mosby; 2012. p. 211-51.

25. Kelly JR, Rose TC. Nonprecious alloys for use in fixed prosthodontics: a literature review. J Prosthet Dent. 1983;49(3):363-70.

26. O'Brien WJ. Dental porcelains: An outline of dental materials and their chemistry. In: O'Brian WJ, Ryge GWB, editors. An outline of dental materials and their selection. Philadelphia: Saunders;1978. 
27. Ritter AV, Baratieri LN. Ceramic restorations for posterior teeth: guidelines for the clinician. J Esthet Dent 1999;11(2):72-86.

28. Wataha JC. Alloys for prosthodontic restorations. J Prosthet Dent. 2002;87(4):351-63.

29. Wataha JC. Biocompatibility of dental casting alloys: a review. J Prosthet Dent. 2000;83(2):223-34.

30. Koutayas SO, Vagkopoulou T, Pelekanos S, Koidis P, Strub JR. Zirconia in dentistry: part 2. Evidencebased clinical breakthrough. Eur J Esthet Dent. 2009;4(4):348-80.

31. Kramer N, Frankenberger R. Clinical performance of bonded leucitereinforced glass ceramic inlays and onlays after eight years. Dent Mater. 2005;21(3):262-71.

32. Magne P, Belser U. Bonded Porcelain Restorations in the anterior dentition a biomimetic approach. 1st ed. Quintessence Publishing Carol Stream, IL;2002.

33. Mörmann WH, Brandestini M, Lutz F, Barbakow F. Chairside computer-aided direct ceramic inlays. Quintessence Int. 1989;20(5):329-39. 